\title{
Forskningsnytt
}

Nytt fra internasjonal forskning presentert og kommentert av Anners Lerdal,

redaktør i Sykepleien Forskning og førsteamanuensis ved Høgskolen i Buskerud.

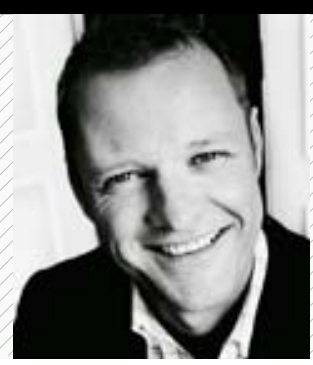

\section{Smerter hos pasienter på norske sykehjem}

Mellom 30-40 prosent av pasientene som hadde smerter fikk ikke smertestillende medisin. Dette går frem av funnene i en studie som beskriver forekomst av smerter blant sykehjemspasienter og deres bruk av smertestillende medikamenter.

I denne tverrsnittsstudien ble data samlet inn ved intervjuveiledet utfylling av spørreskjema og ved at pasientenes primærsykepleiere vurderte deres smerteatferd på en standardisert måte. Innlagte pasienter over 65 år ved syv norske sykehjem i Midt-Norge ble forespurt om å delta i studien i perioden 2005 og 2006

Studien viser at smertevurdering og - lindring av eldre pasienter i sykehjem bør gis større oppmerksomhet. Kan årsaken til at pasienter med redusert kognitiv funksjon rapporterte mindre smerter enn dem med normal kognitiv funksjon skyldes at de har en annerledes smerteopplevelse?
Selvrapportert smerteintensitet ble kartlagt ved hjelp av en firepunkts graderingsskala. For pasienter med redusert kognitiv funksjon, ble pasientenes smerter vurdert av primærsykepleierne gjennom registrering av deres smerterelaterte atferd (Dopolus-2). Ved bruk av denne metoden vurderes ti atferdsområder bestående av tre kategorier: somatisk, psykomotorisk og psykososial atferd. Vurderingen skåres på en skala fra null til tre som summeres til en samleskala fra null til 30. Pasienter med en skår høyere enn fem ble vurdert til å ha smerter. I tillegg ble det samlet inn opplysninger om sosiodemografiske forhold, funksjonsnivå, bruk av smertestillende medikamenter og smerterelaterte diagnoser.

Blant de 307 pasientene som var innlagt ved sykehjemmene, deltok 70 prosent i studien. Gjennomsnittsalderen på deltakerne var 86 år og over to tredjedeler var kvinner. Seksti prosent av smertedataene var selvrapportert smerte.
I gruppen med selvrapportert smerte oppga 51 prosent at de hadde smerter, hvorav fjorten prosent hadde sterke smerter og 31 prosent moderate. I gruppen hvor smerter ble vurdert, hadde 67,5 prosent av pasientene smerter. De oftest forekommende smerterelaterte diagnosene var hjerneslag (34 prosent) og benbrudd (24 prosent). Blant gruppen med selvrapportert smerte, fikk 28 prosent ingen medikamentell smertebehandling, mens denne andelen var 38 prosent i gruppen med vurdert smerte. Studien fant at pasienter med dårligere kognitiv funksjon hadde en tendens til å rapportere mindre smerter

En relativt høy andel av pasientene i sykehjemmene som hadde smerter fikk ingen medikamentell smertebehandling.

\section{REFERANSE}

Torvik K, Kaasa S, Kirkevold O, Rustøen T. Pain in patients living in Norwegian nursing homes. Palliat Med 2008 doi:10.1177/0269216308098800.

\section{Smerter hos pasienter med beinmetastaser}

Eldre kreftpasienter innlagt i sykehus hadde sterkere smerter, men fikk mindre sterke smertestillende medikamenter enn dem som var yngre. Dette var ett av funnene i en studie som kartla forskjeller smerteintensitet, medikamentell smertebehandling og tilfredshet med smertebehandling mellom eldre og yngre kreftpasienter med beinmetastaser.

Forskningsspørsmålene ble besvart ved hjelp av en tverrsnitts- studie hvor alle sykehus i Norge ble bedt om å kartlegge smerter og smertebehandling én bestemt dag i mai 2004. Den norske kortversjonen av Brief Pain Inventory (BPI) ble brukt til smerteregistrering. Spørreskjemaet består av to dimensjoner. Smerteintensitet som handler om smerteopplevelse de siste 24 timer. I hvilken grad smertene påvirket pasientenes generelle aktivitet, $s \varnothing v n$ og tilfredshet med livet anga smertens innvirkning på fungering. Disse opplysningene ble registrert på en skala fra 0-10. Den medikamentelle smertebehandlingen pasientene fikk ble kartlagt og inndelt i tre styrkegrader.

Av 138 pasienter med kreft og beinmetastaser, deltok 57 prosent i undersøkelsen. I gruppen eldre over 65 år ( $n=39)$, varierte alderen fra 66-88 år og gjennomsnittsalderen var 76 år. I den resterende delen av utvalget $(n=40)$ varierte 